I. Romanenko ${ }^{1}$, A. Shyshatskyi ${ }^{1}$, O. Kuvshinov ${ }^{2}$, R. Pikul ${ }^{3}$

${ }^{1}$ Central research Institute of weapons and military equipment of Armed Forces of Ukraine, Kyiv, Ukraine

${ }^{2}$ Management of normative and methodological support and monitoring of the possession, use and disposal of real estate and land, Kyiv, Ukraine

${ }^{3}$ Military unit A 0351, Kyiv, Ukraine

\title{
METHODS OF PREVIOUS CODING, THAT USES IN SYSTEMS OF RADIO SPECIAL PURPOSE WITH MASSIVE-MIMO TECHNOLOGY
}

\begin{abstract}
Modern radiocommunication systems of special purpose function in the conditions of shortage of radio resources and active radio-electronic suppression. One of the ways to increase noise immunity, bandwidth and capacity of communication networks is using antenna arrays, namely, MASSIVE-MIMO technology. However, the possibilities of this technology are not used in full. In order to increase the efficiency of the using of MASSIVE-MIMO technology, the authors of this article are considered methods of pre-coding. The analysis is intended to decompose existing methods of pre-coding for the further development of highly effective algorithms of pre-coding. In the above scientific work, the authors of the article uses the basic provisions of the theory of communication, the theory of signals, the theory of noise immunity, as well as the theory of antennas. According to the results of the research, the authors draw the following conclusions: the matrices of the previous coding, which have the same right singular vectors, which are the optimal for all criteria; the main difference between the previous coding algorithms, that can be obtained by various synthesis criteria is the different distribution of the radiated power between the spatial rays. Thus, the analysis showed, that thanks to the identical structure of the work of linear pre-coders, it is possible to carry out a dynamic change on the transmission side of the type of the linear pre-coder, thereby adaptively modifying the characteristics of the transmission and transmission path, while remaining within the framework of practically one structure of the communication channel.
\end{abstract}

Keywords: Massive-MIMO, previous coding, signaling situation.

\section{Introduction}

In the modern wireless systems, MIMO technology (Multiple Input Multiple-Output) is widely using. This technology involves the using of several antennas on the transmitting and receiving sides, which makes it possible to realize the spatial diversity of signals at reception and transmission, as well as multiplexing of transmitted information [1-8] in radio networks.

The effect of using of the spatial diversity is related to the reception or transmission of the same signal by several antennas. In a fading channel, it allows receiving on the receiving side several versions of the transmitted signal and, due to their statistical processing, more accurately detect the signal.

Recently, a series of publications dedicated to Massive-MIMO technology, technologies "with a large number of antenna elements" $(4 \times 8,16 \times 8$, etc.) [9-13] appeared.

In this case, the antennas can be combined into compact-local groups (sublattices) or have the form of a distributed antenna system on an antenna system of arbitrary plurality of antenna elements, including fractal topologies, that can overlap, but without using of common antenna emitters [10].

Using of Massive-MIMO technology can increase the capacity of radiocommunication networks, their throughput and noise immunity[9-13].

Increasing the bandwidth of Massive-MIMO radio communication systems, while preserving the quality of reception requires the solution of the problem of efficient management of the available spatialfrequency-time resources of these systems. The problem of adaptation of modern radiocommunication networks, including the Massive-MIMO networks, to external conditions, is actively explored in recent years [9-18].

Spatial multiplexing and spacing are contradictory to the geometry and probabilistic characteristics of the channel matrix. Theoretically proved [9-18], that if the channel information is available only to the receiver, then there is a fundamental trade-off between multiplexing and spacing, in which one can not increase one and not reduce another. The situation changes if we assume, that some parameters of the communication channel are known on the transmitting side and can be used to construct the corresponding spatial signal-code structure.

In fact, such systems assume the presence of a reverse link, and the procedure for the formation of an optimal signal-code structure in these conditions is called spatial pre-coding.

In previous publications, the authors of the article noted, that the using of information on the state of the communication channels on the transmitting side can significantly increase both, the energy and frequency efficiency of special purpose radio systems, improve the coverage area and reduce the complexity of the implementation of the receiver system using MassiveMIMO [9-13].

In the general case, linear pre-coding can be considered as one of the methods of spatial-temporal coding. It should be borne in mind, that for the linear pre-coding, the presence of feedback is mandatory, since the matrix of the previous coding is selected, based on the status of the channel [9-13].

Therefore, the purpose of the article is to analyze the methods of pre-coding in radio communication systems, using Massive-MIMO technology. 


\section{Presentation of the main material}

The physical essence of the previous encoding in Massive-MIMO radio communication systems is ,that the pre-coding allows you to reconcile the transmitted signal with the characteristics of the communication channel. This results in improved performance compared to the system without such an agreement.

In the case, where the complex matrix of channel $\mathbf{H}$ is accurately known on the transmitting side, an optimal pre-coding can be done, which is to linearly transform the vector of symbols transmitted, using the unitary matrix $\mathbf{V}$, which depends on the matrix $\mathbf{H}$.

The matrix $\mathbf{V}$ is part of the singular expansion of the matrix $\mathbf{H}$ [1-4]:

$$
\mathbf{H}=\mathbf{U} \boldsymbol{\Lambda} \mathbf{V}^{\prime},
$$

where $\mathbf{U}, \mathbf{V}$ - unitary dimension matrices of $M \times M$ and $N \times N$ respectively; $\Lambda=\operatorname{diag}\left\{\lambda_{1}, \lambda_{2}, \ldots, \lambda_{r}\right\}-$ diagonal matrix of $M \times N$ size, on the main diagonal of which has its own numbers $\lambda_{i}, i=1, \ldots, r$ matrix $\mathbf{H}$; $r=\min \{N, M\}$.

With optimal pre-coding, the best characteristics of the Massive-MIMO radio communication system are achieved, due to the fact, that the system in this case is decomposed into a plurality of parallel systems SISO (Single Input Single Output), the minimal complexity of the demodulation algorithm is provided. on the reception side [1-18].
Unfortunately, in practice, the implementation of optimal pre-coding is quite problematic, because the matrix of the channel $\mathbf{H}$ is always evaluated with some error, especially in a situation, where channel parameters change rapidly, due to the high mobility of subscribers. Therefore, in modern radio systems in practice, various quasi-optimal algorithms of precoding are used [1-18]. In the quasi-optimal algorithms indicated on the transmitting side, instead of full information about the state of the channel contained in the matrix $\mathbf{H}$, only partial information about the status of the communication channel is used. The indicated partial information may be in the form of one or more parameters, that characterize the current state of the communication channel or only its statistics (the law of fading, the distribution of power between the direct and reflected beam in the channel).

To date, there are three main ways to get information about the state of the communication channel:

- using of the mutual linearity of the communication channel;

- using the feedback line between the transmitter and the receiver;

- combination of the first and second methods.

We shall now confine ourselves to considering linear coding algorithms.

Consider the radiocommunication system using Massive-MIMO technology, the structure of which is shown on fig. 1.

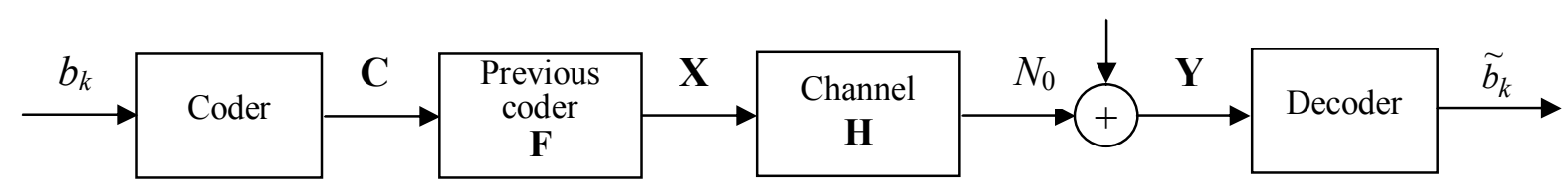

Fig. 1. Generalized description of the system Massive-MIMO

In the indicated scheme on the transmitting side, after the encoder (which here includes the modulator), the signal is subjected to linear transformation using the matrix $\mathbf{F}$ and then enters the Massive-MIMO communication channel with the channel matrix $\mathbf{H}$. The linear transformation matrix $\mathbf{F}$ defines the linear precoding algorithm.

The type of encoder and modulator has a significant effect on the structure of the previous coding algorithm. In the synthesis of pre-coding algorithms, two architectures of the MIMO communication system are usually considered:

- Massive-MIMO system with spatial multiplexing. In such a system, independent information flows are transmitted through all antennas, in which a separate adaptation of the transmission rate for each transmitting antenna is possible, using the information on the state of the communication channel available on the transmitting side;

- Massive-MIMO system with spatial-temporal encoding.

The pre-coding procedure based on the using of the communication channel status, information available on the transmitting side provides two functions: splitting the transmitted signal into independent spatial flows (rays); - distribution of the power of emitted signals between these spatial flows (rays).

If spatial flows (rays) exactly correspond to the own (singular) vectors of the matrix $\mathbf{H}$ of the channel, then there are no interferences between these flows. The transmission of information by a communication channel in this case is carried out in parallel in several independent spatial channels, and for realization of such an ideal data transfer, it is necessary, that on the transfer side accurate information about the current state of the communication channel.

If on the transmitting side, the information about the communication channel is known only partially, then in the previous encoding, the spatial flows (rays) were formed in such a way as to minimize the level of interference between them. It should be noted, that as the number of transmitting antennas increases, the number of degrees of freedom increases, which allows for a more significant energy gain from the previous coding, which confirms the additional advantage of using Massive-MIMO technology in comparison with the classical MIMO technology.

The signal model in the Massive-MIMO communication system with linear pre-coding can be given in the following form: 


$$
\mathbf{Y}=\mathbf{H F C}+N_{0},
$$

where $\mathbf{H}$ is the matrix channel, $N_{0}$ is the white gaussian noise with spectral density of power

$$
G(f)=G_{0} ; 0<f<\infty,
$$

$\mathbf{F}$ is the pre-coded channel matrix, $\mathbf{C}$ is the code matrix of the channel. This model is valid for both spatial multiplexing and spatial-temporal coding. Consider the basic criteria, used to synthesize the previous coding algorithm, the criteria, that allow us to determine the optimal matrix of the previous coding $\mathbf{F}$ [6-19].

Criterion of mutual information. It is known, that the mutual information between the input and output signals of the communication system channel using the Massive-MIMO technology is described by the following expression [20]:

$$
\mathbf{I}(\mathbf{X}, \mathbf{Y})=\log _{2} \operatorname{det}\left(1+Q^{2} \mathbf{H F U F}^{\prime} \mathbf{H}^{\prime}\right)
$$

where $Q^{2}=E_{c} / G_{0}$ is the ratio of the signal energy to the spectral density of the power of the receiver's own noise, $\mathbf{U}$ is the correlation matrix of code matrix.

As shown in [21], the bandwidth of the MassiveMIMO channel is determined by maximizing the mutual information under the condition of the constancy of the radiated power. Then, the criterion of mutual information has the form:

$$
\max _{\operatorname{tr}\left(\mathbf{F F}^{\prime}\right)=1} \mathbf{E H}\left\{\log _{2} \operatorname{det}\left(1+Q^{2} \mathbf{H} \mathbf{F} \mathbf{U F}^{\prime} \mathbf{H}^{\prime}\right)\right\},
$$

where $\operatorname{tr}(\cdot)$ is the step operator.

Criterion for minimizing the avarage square error. The expression for the correlation matrix of demodulation errors, optimal for the criterion of the minimum of the avarage square error, has the form:

$$
R_{M A S E}=\left(1+Q^{2} \mathbf{H F U F}^{\prime} \mathbf{H}^{\prime}\right)^{-1}
$$

The criterion for minimizing the avarage square error is to find such a matrix of pre-coding, in which the minimum value is ensured of the average square of the error $\varepsilon$ demodulation [21, 22]:

$$
\min _{\operatorname{tr}\left(\mathbf{F F}^{\prime}\right)=1} E_{\mathbf{H}}\left\{\operatorname{tr}\left[\left(1+Q^{2} \mathbf{H} \mathbf{F} \mathbf{U} \mathbf{F}^{\prime} \mathbf{H}^{\prime}\right)^{-1}\right]\right\} .
$$

I would like to note, that the criteria (5) and (6) considered require averaging over the distribution of random elements of the matrix, $\mathbf{H}$ of the communication channel of some function $f(.$.$) matrix$ argument $1+Q^{2} \mathbf{H} \mathbf{F} \mathbf{U F}^{\prime} \mathbf{H}^{\prime}$, which depends on the type of criterion:

$$
\max _{\operatorname{tr}\left(\mathbf{F F}^{\prime}\right)=1} E_{\mathbf{H}}\left\{f\left(1+Q^{2} \mathbf{H F U F}^{\prime} \mathbf{H}^{\prime}\right)\right\},
$$

where $f(\ldots)=\log _{2} \operatorname{det}(\ldots)$ when using the criterion of mutual information, and $f(\ldots)=\operatorname{tr}\left[(\ldots)^{-1}\right]$ is using the criterion of the minimum of the square root error.
Calculation of mathematical expectation $E_{\mathbf{H}}\{\ldots\}$ is a rather complicated operation, which limits the practical using of the criteria (4) and (6).

In this regard, it is quite attractive in terms of simplifying the criteria implementation, in which the calculation of mathematical expectation is not used. These criteria include the minimum criterion for the probability of a double error codeword (Pairwise codeword Error Probability - PEP). For the case, where the Massive-MIMO communication channel only has a fading correlation on the transmitting side $\left(\mathbf{R}_{r}=1\right.$ ), the following criterion is known [23-31]:

$$
\max _{\operatorname{tr}\left(\mathbf{F F}^{\prime}\right)} \operatorname{tr}\left(\overline{\mathbf{H}}\left(\mathbf{R}_{t} \Psi \mathbf{R}_{t}^{\prime}\right)^{-1} \overline{\mathbf{H}}^{\prime}\right)-M \log _{2} \operatorname{det}(\Psi),
$$

where $\Psi=\left(Q^{2} / 4\right) \mathbf{F} \mathbf{B} \mathbf{F}^{\prime}+\mathbf{R}_{t}^{-1} ; \mathbf{B}$ is the matrix of code distances, $\overline{\mathbf{H}}$ is the average value of the channel matrix.

Let's consider on the main types of linear precoders used in radio communication systems, using technology Massive-MIMO [23-31].

Provided $\operatorname{tr}\left(F^{H} F\right)=P_{0}$ where $P_{0}$ is the total average transmitted power, should be distinguished:

1. A linear pre-coder, that minimizes the receiver's avarage square error (Min-Trace-VSE Loading):

$$
\mathbf{F}_{\text {opt }}=\underset{\mathbf{F}}{\arg \min } \operatorname{Tr}\{M C K \Pi(\mathbf{F})\} .
$$

2. Linear pre-coder, maximizing the minimum value of the matrix SNR (F) (Max Min-Eig-Signal to noise ratio):

$$
\mathbf{F}_{\text {opt }}=\underset{\mathbf{F}}{\arg \min } \lambda_{\min }\{\operatorname{SNR}(\mathbf{F})\} .
$$

3. A linear pre-coder, that maximizes the mutual information between transmitted $b_{k}$ and accepted $\tilde{b}_{k}$ data (Max-Capasity Loading): $\mathbf{F}_{\text {opt }}$

$$
\mathbf{F}_{\text {opt }}=\arg \max _{\mathbf{F}} C\{b, \tilde{b} \mid \mathbf{F}\},
$$

where $C$ is the bandwidth of the channel.

Their specific choice depends on the channel status, the presence of active interference, the type of selected signals (OFDM, N-OFDM, FHSS, etc.) and the requirements for their demodulation errors..

\section{Conclusion from this explosion}

According to the results of the research, the following conclusions should be made:

1. The matrixes of the previous coding $\mathbf{F}$, which are optimal in all of the above criteria and are intended for using in conditions of different volumes of information on the transmitting side of the properties of the Massive-MIMO communication channel, have the same right singular vectors.

On the basis of these vectors, an optimal matrix of pre-coding $\mathbf{V}_{\mathbf{F}}$ is formed, which will be coordinated with the correlation matrix $\mathbf{Q}$ of the space-time code. 
2. The matrixes of the previous coding $\mathbf{F}$, which are optimal for the criteria of mutual information and the minimum of the avarage square error, also have the same right singular vectors. These vectors determine the direction of spatial rays, which depend on the transmission channel information available on the transmitting side.

3. The main difference between pre-coding algorithms, that can be obtained by various synthesis criteria is the different distribution of the radiated power between spatial rays.

This power distribution is based on the using of the principle of "pouring water".

4. The algorithm of the previous coding in the optimal way (in the sense of the selected criterion) redistributes the signal strength between the spatial rays, using the information on the communication channel on the transmitting side.

5. Thus, the analysis showed, that thanks to the identical structure of the work of linear pre-coders, it is possible to carry out a dynamic change on the transmission side of the type of the linear pre-coder, thereby adaptively modifying the characteristics of the transmission and transmission path, while remaining within the framework of practically one structure of the communication channel.

The direction of further research is to compare the effectiveness of various methods of pre-coding for systems of radio communication with technology Massive-MIMO and their corresponding improvement.

\section{REFERENCES}

1. Slusar, V. (2005), "MIMO systems: principles of construction and signal processing", Electronics: science, technology, business, No. 8, pp. 52-58.

2. Dubik, A.N., Slusar, V.I. and Zinchenko, A.A. (2006), "Using of MIMO-systems to improve the reliability of telecommunications critical applications", Radio electronic and computer systems, National aerospace university named after M.E. Zhukovskiy “KhAI”, Kharkiv, No. 6 (18), pp. 206-209.

3. Slusar, V.I., Masesov, N.A. and Slusar, I.I. (2006), "Increasing of reliability of communication in local wireless networks due to use of methods of space-time signal processing", Radio electronic and computer systems, National aerospace university named after M.E. Zhukovskiy “KhAI”, Kharkiv, No. 7 (19), pp. 195-198.

4. Bakulin, M.G., Varukina L.A. and Kreyndelin V.B. (2014), MIMO technology: principles and algorithms, Hot line Telecom, Moscow, $244 \mathrm{p}$.

5. Tsoulos, G. (2006), MIMO System Technology for Wireless Communications, Boca Raton, CRC Press, FL, USA, 378 p.

6. Jankiraman, M. (2004), Space-Time Codes and MIMO systems, Artech House, MÂ, USA, 327 p.

7. Bessai, H. (2005), MIMO Signals and Systems, Springer science and Business Media, USA, NY, 206 p.

8. Kuvshinov, O.V. (2009), "Adaptive management of devices to prevent the protection of military radiocommunication systems", Collection of scientific works MIKNU, No. 1, pp. 125-130.

9. Slusar, I.I., Slusar, V.I. and Tarasenko, V.V. (2016), "5th generation communication systems, based on Massive MIMO technology", Abstracts of the fourth international scientific and technical conference "Problems of informatization", $3-4$ November, Cherkasy - Baku - Belsko-Byala - Poltava, pp. 63-64.

10. Slusar, V.I. (2017), "Concerning the adaptive control of Massive MIMO channels", 17-th scientific and technical conference "Creation and modernization of armament and military equipment in modern conditions", State scientific and testing center of the Armed Forces of Ukraine, Chernihiv, 07-08 September, pp. 328-329.

11. Slusar, I.I., Slusar, V.I., Deriy, R.S. and Dovbish, R.M. (2017), “Technical aspects of the implementation of advanced MIMO technologies", Abstracts of the fifth international scientific and technical conference "Problems of informatization", 13 - 15 November, Cherkasy - Baku - Belsko-Byala - Poltava, pp. 81.

12. Shyshatskyi, A.V. and Zhuk, P.V. (2017), "Perspective of signal-code designs for wireless communication systems of the standard 5G", Scientific-practical conference "Priority directions of development of telecommunication systems and networks of special purpose", Application of subdivisions, complexes, communication facilities and automation in ATO" $9-10$ November (Reports and abstracts), MITI, Kyiv, pp. 269-270.

13. Shyshatskyi, A.V., Bashkirov, O.M. and Kostina, O.M. (2015), "Development of integrated communication and data communication systems for the necessity of the Armed Forces", Scientific and technical magazine "Armament and military equipment", CRIME AF of Ukraine, Kyiv, No. 1 (5), pp. 35-40.

14. Biglieri, E., Calderbank, R., Constantinides, A., Goldsmith, A., Paulraj, A. and Poor, H.V. (2007), MIMO Wireless Communication, UK: Cambridge Univ. Press, Cambridge, 323 p.

15. Volchkov, V.P. and Shurahov, A.A. (2012), "Investigation of the efficiency of linear precoding algorithms in MIMO systems", Electrocommunication, No. 5, pp. 15-16.

16. Yuen, C. and Tjhnng, T.T. (2007), Communications and Signal processing. Vol 2. Quasi-Orthogonal Space-Time Codes, Imperial College Press, London, UK; 194 p.

17. Sesia, S., Toufik, I. and Baker M. (2009), LTE-The UMTS Evolution: From Theory to Practice, Wiley Sons, Chichester, U.K., $611 \mathrm{p}$.

18. Foschini, G.J. and Gans, M.J. (1998), "On Limits of Wireless Communications in a Fading Environment When Using Multiple Antennas", Wireless Personal Communications, Vol. 6, pp. 311-335.

19. Telatar, E. (1999), “Capacity of Multi-Antenna Gaussian Channels", European Transactions on Telecommunications, Vol. 10, No. 6, pp. 585-595.

20. Vu, M. and Paulraj, A. (2003), "Some asymptotic capacity results for MIMO wireless with and without channel knowledge at the transmitter", Proc. 37th Asilomar Conf. Sig., Sys. and Comp. 2003, Vol. 1, pp. 258-262. 
21. Balaban, P. and Salz, J. (1992), "Optimum diversity combining and equalization in digital data transmission with applications to cellular mobile radio. Part I: Theoretical considerations", IEEE Trans. Commun., Vol. 40, No. 5, pp. 885-894.

22. Jongren, G., Skoglund, M. and Ottersten, B. (2002), "Combining beamformimg and orthogonal space-time block coding”, IEEE Trans. Inform. Theory, Vol. 48, No, 3. pp. 611-627.

23. Haustein, T. and Boche, H. (2003), "Optimal power allocation for MSE and bit-loading in МГМО systems and the impact of correlation “, Proc. IEEE Int. Conf. on Acoustics, Speech, and Signal Processing, Vol. 4, pp. 405-408.

24. Vu, M. (2006), Exploiting Transmit Channel Side Information in MIMO Wireless Systems, Stanford University, PhD. Diss. 2006.

25. Vu, M. and Paulraj, A. (2006), "Optimal linear precoders for MIMO wireless correlated channels with non-zero mean in space-time coded systems”, IEEE TYans. Signal Processing, Vol. 54, pp. 2318-2322.

26. Visotsky, E. and Madhow, U. (2001), "Space-time transmit precoding with imperfect feedback", IEEE TVans. Inform. Theory, Vol. 47, No. 6, pp. 2632-2639.

27. Sampath, H. and Paulraj, A. (2002), "Linear precoding for space-time coded systems with known fading correlations", IEEE Commun. Lett, Vol. 6, No. 6, pp. 239-241.

28. Visotsky, E. and Madhow, U. (2001), "Space-time transmit precoding with imperfect feedback", IEEE Trans. Inform. Theory, Vol. 47, No. 6, pp. 2632-2639.

29. Li, J. and Stoica, P. (2009), MIMO Radar Signal Processing, John Wiley \& Sons, New Jersey, USA, 448 p.

30. Schubert, M. and Boche, H. (2002), "Joint "dirty-paper" precoding and downlink beamforming", Proc. IEEE International Symposium on Spread Spectrum Techniques and Applications, Prague, Czech Republic, September, 2002.

Надійшла (received) 23.01.2018

Прийнята до друку (accepted for publication) 11.04.2018

\section{Методи попереднього кодування, \\ що використовуються у системах радіозв'язку спеціального призначення з технологісю Маssive-MIMO}

І.О. Романенко, А.В. Шишацький, О.В. Кувшинов, Р.В. Пікуль

Сучасні системи радіозв'язку спеціального призначення функціонують в умовах дефіциту радіоресурсу та активного радіоелектронного подавлення. Одним 3 шляхів підвищення завадозахищеності, пропускної здатності та ємності мереж зв'язку є використання антенних масивів, а саме технології MASSIVE-MIMO. Проте можливості зазначеної технології використовуються не в повному обсязі. 3 метою підвищення ефективності використання технології MASSIVE-MIMO авторами зазначеної статті розглянуті методи попереднього кодування. Зазначений аналіз має на меті провести декомпозицію існуючих методів попереднього кодування для подальшої розробки високоефективних алгоритмів попереднього кодування. В зазначеній науковій праці авторами статті використані основні положення теорії зв'язку, теорії сигналів, теорії завадозахищеності, а також теорії антен. За результатами дослідження авторами зроблені наступні висновки: матриці попереднього кодування, що оптимальні по всіх критеріях мають одні й ті ж самі праві сингулярні вектори; основна відмінність між алгоритмами попереднього кодування, які можливо отримати за допомогою різних критеріїв синтезу, полягає в різному розподілі випромінюваної потужності між просторовими променями. Таким чином, проведений аналіз показав, що завдяки однаковій структурі розглянутих у роботі лінійних попередніх кодерів, можливо проводити динамічну зміну на передавальній стороні типу лінійного попереднього кодеру, тим самим адаптивно змінювати характеристики приймально-передавального тракту, при цьому лишаючись в рамках практично однієї структури каналу зв'язку.

Ключов і слов а: Massive-MIMO, попередне кодування, сигнальна обстановка.

\section{Методы предварительного кодирования, используемые в системах радиосвязи специального назначения с технологией Massive-MIMO}

И.О. Романенко, А.В. Шишацкий, А.В. Кувшинов, Р.В. Пикуль

Современные системы радиосвязи специального назначения функционируют в условиях дефицита радиоресурса и активного радиоэлектронного подавления. Одним из путей повышения помехозащищенности, пропускной способности и емкости сетей связи является использование антенных массивов, а именно технологии MASSIVEMIMO. Однако возможности указанной технологии используются не в полном объеме. С целью повышения эффективности использования технологии MASSIVE-MIMO авторами указанной статье рассмотрены методы предварительного кодирования. Указанный анализ имеет целью провести декомпозицию существующих методов предварительного кодирования для дальнейшей разработки высокоэффективных алгоритмов предварительного кодирования. В указанной научной работе авторами статьи использованы основные положения теории связи, теории сигналов, теории помехозащищенности, а также теории антенн. По результатам исследования авторами сделаны следующие выводы: матрицы предварительного кодирования, оптимальные по всем критериям имеют одни и те же правые сингулярные векторы; основное различие между методами предварительного кодирования, которые можно получить с помощью различных критериев синтеза, заключается в различном распределении излучаемой мощности между пространственными лучами. Таким образом, проведенный анализ показал, что благодаря одинаковой структуре рассмотренных в работе линейных прекодеров, возможно проводить динамическую смену на передающей стороне типа линейного предварительного кодера, тем самым адаптивно изменять характеристики приемопередающего тракта, при этом оставаясь в рамках практически одной структуры канала связи.

Ключевые слов : Massive-MIMO, предварительное кодирование, сигнальная обстановка. 